Uniwersytet PrzyrodniczoHumanistyczny w Siedlcach

Siedlce University of Natural Sciences and Humanities

https://bazawiedzy.uph.edu.pl

\begin{tabular}{|l|l|}
\hline Publikacja / Publication & $\begin{array}{l}\text { The influence of marketing research on logistic decisions in the air transport, } \\
\text { Wąsowska Katarzyna }\end{array}$ \\
\hline $\begin{array}{l}\text { DOI wersji wydawcy / Published } \\
\text { version DOI }\end{array}$ & http://dx.doi.org/10.21008/j.2083-4950.2017.7.4.4 \\
\hline $\begin{array}{l}\text { Adres publikacji w Repozytorium } \\
\text { URL / Publication address in } \\
\text { Repository }\end{array}$ & https://bazawiedzy.uph.edu.pl/info/article/UPH2268a0a82b784b61ade655d9babd5cb1/ \\
\hline $\begin{array}{l}\text { Data opublikowania w Repozytorium } \\
\text { / Deposited in Repository on }\end{array}$ & 22 paź 2021 \\
\hline Rodzaj licencji / Type of licence & Attribution-NoDerivs (CC BY-ND 3.0) O \\
\hline \multicolumn{2}{|l|}{$\begin{array}{l}\text { Wąsowska Katarzyna: The influence of marketing research on logistic decisions in } \\
\text { the air transport, Research in Logistics \& Production, Publishing House of Poznan } \\
\text { University of Technology, vol. 7, no. 4, 2017, pp. 319-326, DOI:10.21008/j.2083- } \\
4950.2017 .7 .4 .4\end{array}$} \\
\hline
\end{tabular}




\title{
THE INFLUENCE OF MARKETING RESEARCH ON LOGISTIC DECISIONS IN THE AIR TRANSPORT
}

\author{
Katarzyna Wąsowska
}

Faculty of Economic and Legal Sciences, Siedlce University of Natural Sciences and Humanities, Żytnia 17/19 St, 08-110 Siedlce, Poland, Email: katarzyna.wasowska@op.pl

\begin{abstract}
Given actions related to the air transport, we can surely conclude that the contemporary air services market is characterized by dynamic growth and development. A quick modification of factors responsible for smooth functioning requires implementation of actions aiming at increasing the quality of offered services by adapting them to the expectations of the air passengers to be taken on a more systematic basis. The above actions will bring effects only if we demonstrate our expert knowledge of the market and its needs. The market of air services in the 21 st century faces strong competition. Therefore, in order to gain information about the factors, processes, and field phenomena, research must be conducted, as it constitutes the basic tool for the shaping of the air services industry. Marketing research conducted in the field of air transport based on a well-structured research scheme allows taking the right logistic decisions, which is the subject of this article.
\end{abstract}

\section{Paper type: Research Paper}

Published online: 30 August 2017

Vol. 7, No. 4, pp. 319-326

DOI: $10.21008 / \mathrm{j} .2083-4950.2017 .7 .4 .4$

ISSN 2083-4942 (Print)

ISSN 2083-4950 (Online)

(C) 2017 Poznan University of Technology. All rights reserved.

Keywords: marketing research in the air transport, air transport, logistic decisions 


\section{INTRODUCTION}

The market of air transport services features fast development and dynamic growth, which is changing its structure and operating conditions. Airport management goes to no end of trouble in order to increase quality of services and meet expectations of all air transport customers. However, the actions managers undertake will have the intended effects only when based on knowledge about current market conditions and its needs.

Effective management of air transport involves gaining and processing of information that originates from, amongst others, targeted research. The market of aviation services is facing multiple problems in the 21 st century, one of them being strong competition. In the light of the above, we can say that systematic collection of data regarding market phenomena, processes and factors is the underlying tool affecting the market as a whole (Rucińska, 2011).

Marketing studies conducted by airlines are key to the shaping of the air services market since they provide necessary information to be used at an appropriate time in processes related to:

- identifying and defining marketing opportunities and risks,

- generating, refining and evaluating marketing actions,

- monitoring marketing performance and improving its understanding (Rucińska, Ruciński \& Tłoczyński, 2012).

With a view to the above, it might be worth quoting the definition of marketing research as presented by the American Marketing Association: the function that links the consumer, customer, and public to the marketer through information information used to identify and define marketing opportunities and problems; generate, refine, and evaluate marketing actions; monitor marketing performance; and improve understanding of marketing as a process. Marketing research specifies the information required to address these issues, designs the method for collecting information, manages and implements the data collection process, analyzes the results, and communicates the findings and their implications (Churchill, 2002).

The diversity of marketing research presented in the Figure below is the result of constant market changes in the field of both micro- and macro-economy, and of the implemented policy of air services market liberalization. The above actions are directed at entities operating in the areas surrounding airports (Tłoczyński, 2004).

On the air service market, both market and marketing studies can be conducted in the following dimensions:

- time - short-, medium-, and long-term;

- geography - space;

- a product-market type of a relation. 


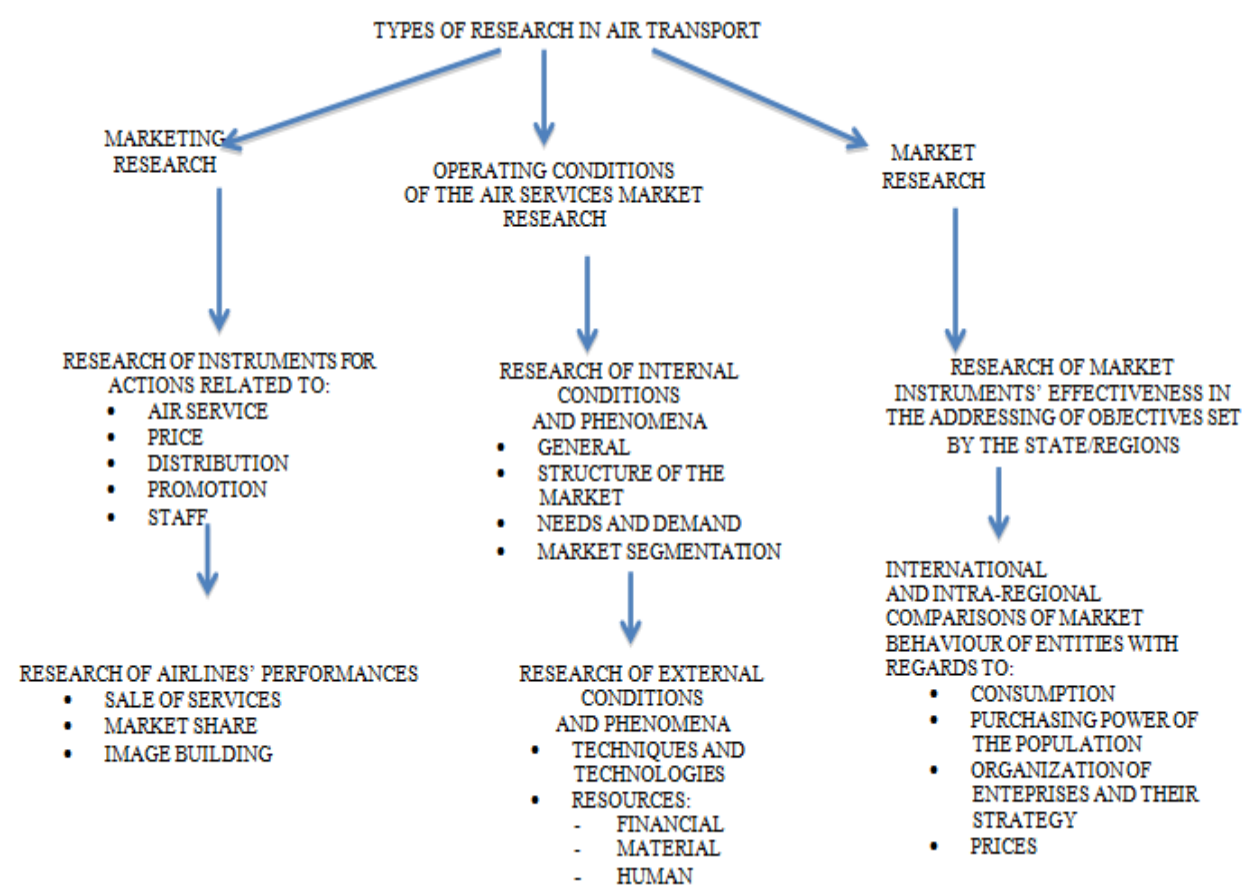

Fig. 1. Types of research in air transport

Marketing research relates to market decisions concerning the following issues:

- increased demand on domestic and international routes;

- adjusting offer to the changing preferences of the user;

- identifying demand for new aviation links;

- better use of the current commercial load and, ultimately, increase of economic efficiency of a given line.

The research process on its own is composed of five cycles including:

- identifying the problem and market research objectives;

- drafting a research plan;

- gathering information;

- preparing an analysis and data evaluation;

- presenting research conclusions.

Airlines very often combine in their practice both quantitative and qualitative research. Sometimes they even use methods from other fields. The most frequently applied research instruments are: a questionnaire or a structured survey, observations, projection methods and heuristics. Research planning involves choosing and selecting source data, type of research, choosing the right instruments, choosing a sample and types of communication with respondents. Currently, statistical data is for the airlines an easy and cheap source of information regarding, for example, the level of income generated by aviation activities. 
Direct research most typically includes primary data collected with the use of adequate techniques and tools. The most well-known of them are: an interview, a questionnaire and observations of passengers at the airports, travel agents, and while on-board.

Interview - the most commonly used research technique serving mainly the purpose of collecting information about the needs and expectations of passengers and the level of trust they have in a given carrier. Airlines apply the following types of interviews in their research:

- a direct interview conducted amongst airline passengers shortly after customs clearance or while on-board.

- a telephone interview conducted amongst passengers that are customers of loyalty programs offered by carriers.

A properly structured questionnaire is helpful for the purpose of conducting an interview (Rucińska, Ruciński \& Wyszomirski, 2004).

Quite useful a research conducted at airports is an experiment which aims chiefly at collecting data regarding the cause and effect of analyzed variables - i.e. the difference between the price of an air service and an alternative mode of transportation.

In addition, airlines carry out so-called marketing tests, which involve an implementation of a particular service for one air link only with the intention to evaluate the effect of such an innovation on potential profitability for other destinations served by the operator. In order to gain in-depth information about the new air service, it is helpful conduct an additional study of consumer groups.

The most common measurement techniques applied during airline passenger observations are: direct measurement, indirect measurement, explicit measurement, implicit measurement, participatory measurement, and non-participatory measurement. At times, for the purpose of collecting information regarding expectationsneeds of passengers regarding a new offer, a user group study may help. Therefore, special associations and committees have been established in some countries, the main tasks of which is to represent passenger interests and views. Also international organizations, such as the International Chamber of Commerce, organize discussion panels on passenger needs development. If collected information is to constitute the basis for strategic planning when taking the right market decisions and for marketing management on the market of air services, it needs to be reduced and analyzed.

Systematic studies regarding the market of air services are also conducted by the largest world manufacturers of the fleet: Boeing Company (an American corporation operating in the air and space sector), EADS (a corporation gathering the largest European manufacturers - Airbus Industry, ATR, Embraer Europe, Pratt $\&$ Whitney, GECAS, International Tease Finance Corporation, CIT Aerospace). Studies on the application of innovative techniques and technologies or air traffic management systems are carried out by research institutes. The results of such studies are disseminated by the Civil Air Navigation Services Organization 
(CANSO). In Poland, research is conducted by governmental organizations responsible for the creation and continuous refinement of air transport operations under conditions of intensive competition (the Civil Aviation Office), and by operators (Lufthansa, British Airways, PLL LOT) and airports. Another source of information regarding the functioning of the air services market are studies carried out by research centers and universities. Yet additional sources are online opinions of buyers and settlement offices for ticket sales. In connection with the aligning of market research standards, all marketing actions - market research - conducted within the territories of the members of the European Union are coordinated and supervised by the European Commission. Systematic air services market research is also performed by the International Air Transport Association (IATA) and Airports Council International (ACI). In Poland, all data regarding the air market is circulated by airports, PLL LOT and the Civil Aviation Office (CAO). Information regarding forms of cooperation with individual carriers is, in turn, provided by travel agents, travel agencies, and tour operators (Rucinska 2011).

Marketing actions conducted within airports are performed by promoting and supporting non-air airport services that have a decisive effect on their income.

By undertaking promotional activities airports highlight their values, i.e. competitive advantage and the following distinguishing factors: the range of aviation links offered, convenience of connections and transfers, shopping offer (including duty free shops), and other non-air services and parking lots, comfort of service, safety, location and land transport, checking-in and airplane servicing times, airport fees, and environmental protection measures.

For the purpose of their marketing actions, airports use various communication channels. The most popular of them are information materials and print advertising, multi-language folders containing information that is useful to passengers (such as flight schedules, airport and terminal maps, access routes, location of parking lots). Furthermore, the airport magazine (a periodical) is available both at the airport and at tourist information offices.

TV and radio advertising is used at times, but the most frequently applied is press advertising covering industry magazines addressed mostly at air carriers.

Airports take tailor-made marketing actions directed at air carriers. One of such actions is direct marketing, which aims at communicating directly with the carriers and at driving them to start or develop new air connections from a given airport. What is essential here is a regular and direct contact with carriers, done typically by periodic industry events and everyday communications within the AOC. Regular meetings encompass discussions regarding, amongst other things, current airport problems, explication of the viewpoints of both parties, and consulted changes. Key to the development of connections is organization of annual conferences, the Routes, where the representatives of carriers and airports can all meet. Organizing specialist conferences by a given airport is highly important in terms of marketing.

Actions addressed directly at passengers include: sending flight schedules and airport magazines to customers by regular or electronic mail. Emails sent to pas- 
sengers and media representatives are newsletters, which allow new connections and other airport offers to be presented not only in the press, but also in the radio and TV news.

From time to time, airports undertake public relations actions, such as "open days", aviation shows, fairs, or airport trips. What is more, they conduct information campaigns aimed directly at the local residents. Additionally, a very important role is played by sponsorship of cultural and sport events organized within the airport perimeter.

The most interesting marketing program that has been run for a number of years now is the Katowice airport's "I fly from Katowice" action. As part of the program, all passengers using the Katowice airport receive a discount on the services provided at the airport (parking lots, catering, shopping, car rentals, guest rooms), and the travel agents and carriers who sell most tickets for flights from Katowice are properly awarded.

Sometimes customers coerce airports to take certain marketing actions, especially when they have a weaker bargaining position. Low-cost carriers often have a rather aggressive airport policy - for example low airport fees in return for opening a new connection. Moreover, they expect marketing support in the form of promotion and advertising of new flight connections, require fees to be paid by local self-governments for promoting the attractiveness of their destinations and staff maintenance costs in destination and home airports to be covered. Such support is frequently offered by airports and local authorities aware of the meaning the traffic generated by carriers has for economic development and generation of employment in the region.

Another crucial marketing tool for an airport is its website, which also contributes to the intensification of air traffic and generation of extra income for the airport management. Such websites fulfil informative and promotional functions and may provide information regarding the tourist and business offer of the cities and regions served. It is essential for information placed online to be available in languages of the countries one wants to have passengers from. Furthermore, websites include data related to hotels and air carriers and tourist offers. They may also offer an online ticket sale, a hotel and conference room booking system, Executive Lounge and VIP services, and an online sale of goods and services available at the airports (e.g. in duty free shops).

An essential element of every airport's marketing actions is its brand and name. It is key to use a name of a well-known place or a patron, for instance Frederic Chopin in Warsaw and Lech Wałęsa in Gdańsk. Airport management uses airport's logo in all information and advertising materials and in the airport's labelling scheme. It is vital that all materials and interior decorations have a common color scheme and uniform graphic motifs, which leave no doubts as to which airport they are associated with (Kaliński 2008). 


\section{CONCLUSION}

Conducting research on the air services market is well-justified, as its results constitute the basis for making good and correct decisions. Analyses are a source of information for companies and bodies operating on both the demand and the supply side of the air services market. Some market participants use their own systems and programs of systematic market information acquisition because they are the key to their success. Thanks to said information, aviation corporations make better choices, develop desired offers, plan new directions for development, and take market decision. Passengers - as the buyers of air services - have an opportunity to avail of new, improved offers and additional benefits.

However, interviews conducted with managers in charge of regional Polish airports show that information from the market is not the direct basis for making managerial decisions.

All actions undertaken within airports are connected with:

- development of a strategy for regions and cities,

- development of a strategy for airport development,

- development of market claims and assumptions regarding a more complete satisfaction of claims filed against air services.

Plans and right marketing actions underpin the activity of airports in the $21 \mathrm{st}$ century. Without them, airports could not operate under conditions of strong competition. Air carriers having a strong market position often dictate conditions to weaker airports unable to meet the challenges of the market.

\section{REFERENCES}

Churchill G.A. (2002), Badania marketingowe. Podstawy metodologiczne PWN.

Kaliński D. (2008), Znaczenie działań marketingowych europejskich portów lotniczych, International Journal of Management and economics, pp. 172-174. Available at http:// www.bazhum.muzhp.pl

Rucinska D. (2011), Badania rynku usług lotniczych. Istota, zakres, użyteczność, przykłady, Zeszyty Naukowe no. 9 - Polskie Towarzystwo Ekonomiczne, pp. 287.

Rucińska D., Ruciński A. \& Tłoczyński D. (2012), Transport lotniczy. Ekonomika i organizacja, Wydawnictwo Uniwersytetu Gdańskiego.

Rucińska D., Ruciński A. \& Wyszomirski O. (2004), Zarządzanie marketingowe na rynku usług transportowych, Wydawnictwo Uniwersytetu Gdańskiego.

Tłoczyński D. (2004), Kierunki rozwoju działalności marketingowej polskich portów lotniczych, Available at http:// www. logistyka.net.pl

\section{BIOGRAPHICAL NOTES}

Katarzyna Wasowska is a $\mathrm{PhD}$ at Faculty of Economic and Legal Sciences, Siedlce University of Natural Sciences and Humanities. She teaches the logistics. 
Her interests are logistic services, international logistics, logistic infrastructure, transport and spedition, as well as transport policies. She is the author and coauthor of papers whose topics are in a field of the air transport: Research process in air transport economics problem-solving and Safety of Air Transport Operations Under Changeable Political and Economic Conditions Around the World. Her papers appear in numerous journals including "Logistyka". 